\title{
Detailed characterization of the Late Pleistocene loess sequence stratigraphy of Remicourt (Hesbaye region, Belgium) with cone penetration tests
}

\author{
SimOn DELVOIE ${ }^{1, *}$, FrédérIC BOULVAIN ${ }^{2}$, ROBERT CHARLIER ${ }^{1}$, FréDÉrIC COLLIN ${ }^{1}$
}

\author{
${ }^{1}$ University of Liège, Department of Architecture, Geology, Environment and Civil Engineering (ArGEnCo), Geomechanics and \\ Engineering Geology Research unit, B52/3, Sart-Tilman, B-4000 Liège, Belgium. \\ ${ }^{2}$ University of Liège, Department of Geology, Sedimentary Petrology Research unit, B20, Sart-Tilman, B-4000 Liège, Belgium. \\ * corresponding author: s.delvoie@ulg.ac.be.
}

\begin{abstract}
Cone penetration tests (CPT) and drilling results are used to characterize the Middle Belgium loess sequence. A two scale study has been realized in the Hesbaye region (Belgium). The study on a regional scale was performed along a $18 \mathrm{~km}$ long section of the high-speed railway Liège-Brussels. About 230 tests were compiled. Results show the loess thickness is very variable and can locally reach $20 \mathrm{~m}$. Tertiary deposits become continuous and they rapidly thicken from Waremme to the West. The lower surface of the Tertiary deposits is characterized by a $0.3 \%$ apparent dipping to the NW. The dipping likely results from the Ardenne Massif uplift. The local scale study focuses on the site of Remicourt located along the high-speed railway. 24 CPT tests have been carried out very close to a series of archaeological trenches. The analysis shows penetrometers are able to define some stratigraphic markers within the loess layer. The most identifiable marker is stratigraphically located around the transition between the Humiferous Complex of Remicourt and the Rocourt Pedocomplex. The lens-shape of the loess ridge is also confirmed by the penetrometers' interpretation. Furthermore, the 3D morphology of each stratigraphic marker can be estimated. These results offer interesting perspectives for the investigation of the loess sequence related to archaeological applications.
\end{abstract}

KEYWORDS: geotechnics, cone resistance, Quaternary, Eemian, Weichselian, stratigraphic marker, Rocourt Pedocomplex.

\section{Introduction}

Loess is an aeolian deposit characterized by a very well sorted grain size distribution predominantly ranging between 10-50 $\mu \mathrm{m}$ (corresponding to coarse silt from ASTM D2487-06). In its detailed definition of loess, Pécsi $(1990,1995)$ added that the weight percentage of the silt fraction corresponds to $40-70 \%$. Geologists, geomorphologists and soil scientists usually consider this material as a sedimentary sequence with heterogeneities even at local scale (palaeosols, unconformity surfaces, palaeovalleys...). In addition to preliminary survey works, characterization of loess and resulting interpretations are classically performed by sedimentological (e.g. Antoine et al., 2013; Guo et al., 2013), pedological (e.g. Ding et al., 1999; Schellenberger \& Veit, 2006), mineralogical (e.g. Smykatz-Kloss et al., 2004; Pouclet et al., 2008; Pouclet \& Juvigné, 2009) and chronostratigraphic (e.g. Buylaert et al., 2008; Roberts, 2008) studies. Results of these studies point out a succession of layers and horizons including removed sediments, eventual tephra (e.g. Pouclet et al., 2008; Pouclet \& Juvigné, 2009) and post-depositional processes as palaeosols formation (e.g. Antoine et al., 2013; Guo et al., 2013; Schellenberger \& Veit, 2006), redox processes, chemical and mineralogical modifications (e.g. Schellenberger \& Veit, 2006). Moreover, loess deposits are very easily erodible, raising the complexity for stratigraphic studies due to the presence of locally eroded layers and unconformity surfaces.

A major limitation for common approaches to characterize the stratigraphy of loess sequences is the need for observable sections for the description, the sampling and the in situ analysis of the sequences. These sections are unfortunately rare, often temporary and not deep enough. An alternative could be sampling from drillings but it becomes expensive for thick loess layers. Moreover, the recognition of horizons based on samples is not always easy.

These limitations lead us to propose another alternative to characterize loess stratigraphy based on cone penetration tests (CPT). Indeed CPT is a common and worldwide test usually performed for civil engineering applications (e.g. estimation of the bearing capacity (Bustamante \& Gianeselli, 1982), settlement (Tonni \& Gottardi, 2011), liquefaction (Zhang et al., 2002)). It is fast, repeatable, and economical, compared to drilling. CPT consists of pushing a cone tip at the end of a series of rods into the ground at constant rate to measure continuously or intermittently the resistance to penetration of the tip. Measurements of the friction resistance on the outer surface of tubes or on a surface sleeve can also be performed. Geotechnicians use CPTs to mechanically characterize subsoil layers in order to provide quantitative data on the mechanical behaviour through depth. But civil engineering applications usually do not focus on a detailed loess stratigraphy study. Geotechnicians usually consider this material as a homogeneous fine soft material. Numerous studies also perform CPTs to distinguish between soil materials for environmental and agricultural applications (e.g. tillage system (Alvarez \& Steinbach, 2009), crop growth (Grunwald et al., 2001)). These applications rarely investigate a depth exceeding two metres beneath the ground surface. In this study the mechanical approach from CPT data is applied to Middle and Late Pleistocene loess located in the eastern part of the Hesbaye region.

\section{Regional geological setting}

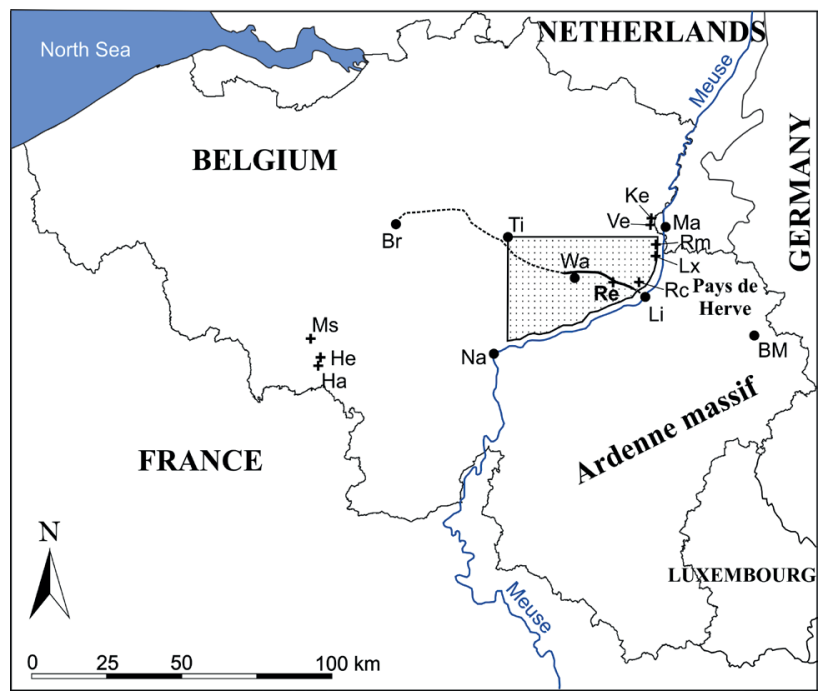

Figure 1. Location map of the places and regions mentioned in this paper. The dotted area represents the extent of the Hesbaye region. The highspeed railway between Liège and Brussels is also located: the solid line corresponds to the investigated section (between Rocourt and Waremme) and the non investigated sections are symbolized by the dotted lines. Abbreviations are used for localities (points): BM = Baraque Michel; $\mathrm{Br}=$ Brussels; $\mathrm{Li}=$ Liège; $\mathrm{Ma}=$ Maastricht; $\mathrm{Na}=$ Namur; $\mathrm{Ti}=$ Tienen; $\mathrm{Wa}=$ Waremme. Well-known Pleistocene investigated sites in Middle Belgium are represented by crosses: $\mathrm{Ha}=$ Harmignies; He = Hélin quarry; $\mathrm{Ke}=$ Kesselt; Lx = Lixhe; $\mathrm{Ms}=$ Maisière-Canal; Rc = Rocourt; $\mathrm{Re}=$ Remicourt; $\mathrm{Rm}=$ Romont quarry; Ve = Veldwezelt. 
The Hesbaye region (Middle Belgium) is a natural region characterized by its cultivated lands. The region has no officially defined borders. It is, however, well-established to place the southern and eastern boundaries of the region at the top of the flank of the Meuse valley (Fig. 1) (e.g. de Heinzelin, 1984). The western limit is approximately a N-S axis extending from the Meuse valley to the city of Tienen. The northern limit is a W-E axis starting from Tienen to the Meuse valley near Maastricht.

\subsection{From Cretaceous to Oligocene}

In Hesbaye, deposits older than Maastrichtian have negligible influence on the surface loess layer. Maastrichtian deposits are mainly composed of grey and white chalk containing continuous flint nodule layers - the Gulpen Formation (Robaszynski, 2006). In the eastern part of the Hesbaye region, the Maastricht Formation composed of calcarenite is on top of the Gulpen Formation (Robaszynski, 2006). A marine regression at the end of Maastrichtian caused erosion and dissolution of the top of the chalk and calcarenite layers, and resulted in a flint nodule conglomerate at the top of the Gulpen Formation. The sea covered again the eastern part of the Hesbaye during Selandian and Thanetian (Paleocene). This resulted in the deposit of the Heers Formation (sands and marls) (Laga \& De Geyter, 1988) and the Hannut Formation (clays, fine sands, siliceous limestones, siltstones and sandstones) (De Geyter, 1988). During Rupelian (early Oligocene) new deposits covered the eastern part of the Hesbaye region. They are related to a marine transgression and are composed of fine sands, silts and clays of the Sint-HuibrechtsHern Formation (Laga, 1988). Evidence of Oligocene deposits has also been found at $700 \mathrm{~m}$ a.m.s.l. at Baraque Michel (Demoulin, 1998). At the end of Oligocene the sea receded for the last time. Finally the Oligocene deposits have been overlaid by aeolian silt layers during Quaternary. These deposits are mainly related to the last glaciation (Weichselian). They compose the Romont Group subdivided into two formations: the Veldwezelt Formation and the Gembloux Formation (Haesaerts et al., 2011a).
The Ardenne massif started to significantly uplift from lower Paleocene (Demoulin, 1995). Due to the evidence of Oligocene marine sands at Baraque Michel, it has been estimated that the Ardenne massif has uplifted at least 400-500 $\mathrm{m}$ in its NE part since Oligocene (Demoulin, 1998). Measurements of the Oligocene deposits basement surface performed on the northern margin of the Ardenne massif around the Pays de Herve region (east of the Liège area) reveal a NNW-dipping of 0.6\% (Demoulin, 1995). This inclination is related to the uplift of the Ardenne massif.

\subsection{During Quaternary}

The aeolian silt deposits found in Middle Belgium belong to the Eurasian loess belt that extends from NW France to Siberia, over Belgium, the Netherlands, Germany, Poland, Ukraine and the Russian Plain (Frechen et al., 2003; Haase et al., 2007; Haesaerts et al., 2009). Many studies have shown evidence of loess stratigraphic correlations between different investigated sites on a regional scale (Haesaerts \& Van Vliet-Lanoë, 1981; Haesaerts et al., 1999; Pirson, 2007) (Fig. 2), and even on a continental scale (Haesaerts et al., 2009). The main studied Middle and Late Pleistocene loess sequences in Middle Belgium are shown in Figure 1 (see cross symbol).

The loess sequence of Middle Belgium is divided into lithostratigraphic units recently defined by Haesaerts et al. (2011a). The definition of the different lithologic and pedological units has often evolved since the first modern version proposed by Gullentops (1954). The most recent definition of the Late Pleistocene units is presented by Pirson et al. (2009) while Haesaerts et al. (2011b) focus on the sequence between Eemian and the beginning of the Weichselian early pleniglacial. The main units are described below, from bottom to top.

The Rocourt Pedocomplex is probably the most studied lithostratigraphic unit in NW Europe due to its palaeoclimatic evolution records and the presence of numerous artifacts (Haesaerts \& Mestdagh, 2000; Haesaerts et al., 2011b; Pirson \& Di Modica, 2011). In Belgium, this unit was firstly defined in
Figure 2. Upper part of Middle Pleistocene and lower part of Late Pleistocene loess sequences correlation in Middle Belgium (modified, after Haesaerts et al., 2011b; TL dating at Rocourt after Van den Haute et al., 2003; IRSL dating at Harmignies after Frechen et al., 2001; drawing by P. Haesaerts; infographic by E. Dermience). Symbols legend: 1. loess; 2. more or less stratified silt; 3. sand; 4. humiferous loess; 5. whitish silt; 6. B2t horizon (leached horizon); 7. B or B2 horizon (brown soil or brown leached soil); 8. Bth horizon (grey forest soil) 9. humiferous horizon; 10 . bleached sediments or tundra gley; 11. iron hydroxides; 12. grey patches (glossic features); 13. biotubes; 14. Rocourt Tephra; 15. artifact. Abbreviations: $\mathrm{HCR}=$ Humiferous Complex of Remicourt; SO = Oligocene sand; VSG $=$ Villers-Saint-Ghislain; WHM = Whitish horizon of Momalle

\section{HARMIGNIES - HELIN}

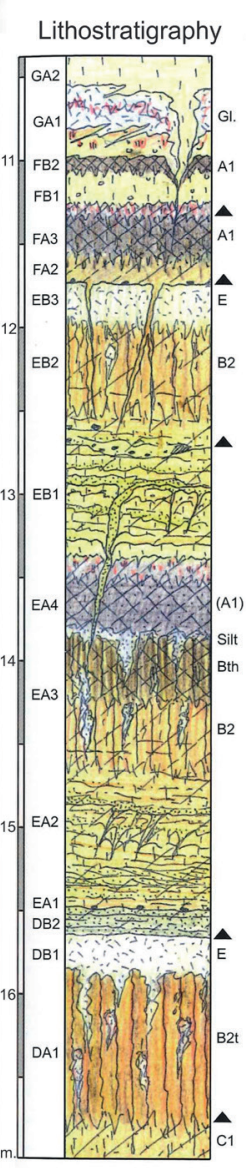

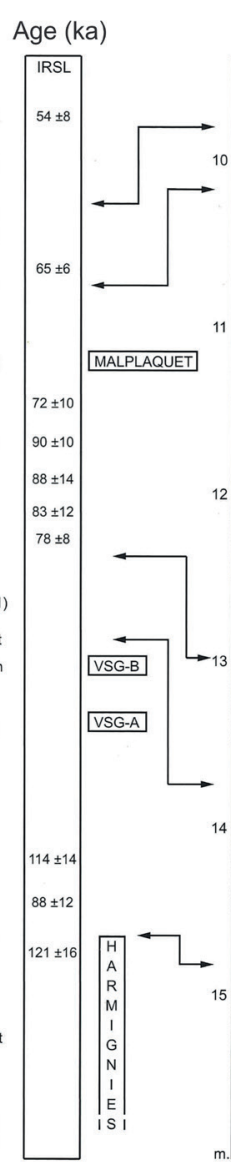

\section{REMICOURT}

Lithostratigraphy

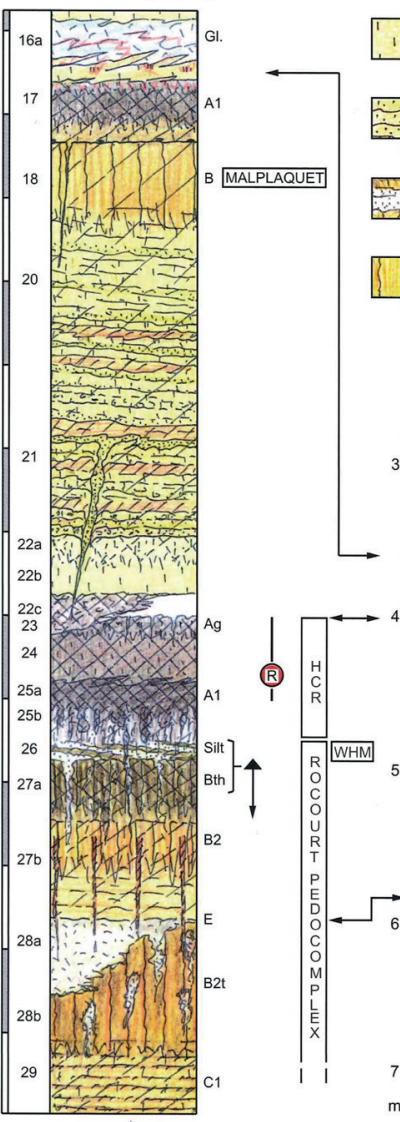

Symbols chart

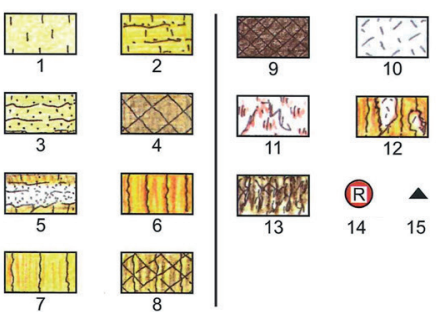

ROCOURT

Lithostratigraphy Age (ka)

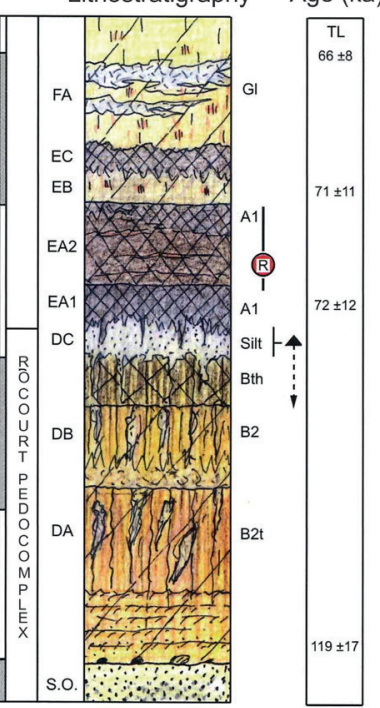


detail as the 'Rocourt Soil' by Gullentops (1954) in the Gritten sand pit (Rocourt, NW of Liège) as a well developed red brown illuviated horizon (B2t) overlain by a $10 \mathrm{~cm}$ thick whitish eluviated horizon (E), all attributed to the last interglacial. Afterwards three distinct pedogeneses have been distinguished. The present-day system allocates the three pedogeneses to the following pedological units: the Harmignies Soil, and the VillersSaint-Ghislain A and B Soils (VSG-A, VSG-B) (Haesaerts, 1978; Haesaerts \& Van Vliet-Lanoë, 1981; Haesaerts et al., 1999, 2011b). The eluviated whitish horizon on the top of the Rocourt pedocomplex has been named Whitish horizon of Momalle (WHM) (Haesaerts et al., 1997a). Thermoluminescence (TL) dating specifies the age for the Rocourt Pedocomplex between 120 and $70 \mathrm{ka}$ (Van den Haute et al., 2003) corresponding to the last interglacial and the Weichselian early glacial. The top of the Rocourt Pedocomplex represents the upper limit of the Hainaut Member of the Veldwezelt Formation (Haesaerts et al., 2011a).

The Rocourt Pedocomplex is overlain by the Humiferous Complex of Remicourt (HCR - named by Haesaerts et al., 1997a from the Remicourt sequence), also named Warneton pedocomplex (Paepe, 1967a, 1967b; see also Van Vliet-Lanoë, 1990). This is a dark horizon, Chernozem-like soil, related to the end of the Weichselian early glacial dated between 100 and $70 \mathrm{ka}$ (TL dating, Van den Haute et al., 2003). More recently correlation with the Greenland reference sequence for Late Pleistocene places the HCR between 80 and $78 \mathrm{ka}$ (Haesaerts et al., 2011b). The HCR is subdivided into three units (Haesaerts et al., 1999; Pirson, 2007). The first one forms the lower third of the layer and is distinguished from the two upper parts by intense bioturbation evidence. The lower and the medium parts are separated by a hiatus. Enstatite-rich volcanic minerals have been discovered in the two upper thirds of the HCR for the first time in the Gritten sand pit (Gullentops, 1954) and afterwards in many other sites in Belgium (Juvigné, 1977; Juvigné \& Semmel, 1988; Juvigné et al., 2008, 2013; Pouclet et al., 2008; Pirson \& Juvigné, 2011). The enstatite-rich tephra was named by Juvigné as the Rocourt Tephra (Juvigné, 1977; Juvigné, 1993). The HCR is included into the Warneton Member of the Gembloux Formation (Haesaerts et al., 2011a).

The Malplaquet Soil is described as an illuviated brown soil (E.B.2 of the Harmignies sequence, Haesaerts \& Van Vliet, 1974) located above the HCR but often separated from it by laminated deposits. It was previously considered as the third pedogenesis of the Rocourt Pedocomplex (Haesaerts et al., 2011b). TL dating gives an age close to $80.2 \pm 8.2 \mathrm{ka}$ for the Malplaquet Soil from the Harmignies sequence (Frechen et al., 2001), in the first half of Weichselian early pleniglacial. The correlation with the Greenland reference sequence positions this soil around $76 \mathrm{ka}$, in agreement with TL data (Haesaerts et al., 2011b).

The Vaux Soil is located in the early Weichselian middle pleniglacial, with an age between ca 40 and ca $42 \mathrm{ka} \mathrm{BP}\left({ }^{14} \mathrm{C}\right.$, Pirson et al., 2006). This is described as an argillaceous illuviated brown soil (H.B.4 of the Harmignies sequence, Haesaerts \& Van Vliet-Lanoë, 1974). The Vaux Soil is attributed to a part of the Vellereille Member of the Gembloux Formation (Haesaerts et al., 2011a).

Higher in the loess sequences, the base of the Brabant Member of the Gembloux Formation is defined by the Nagelbeek Tongued Horizon (NTH, Haesaerts et al., 1981; Haesaerts et al., 2011a), previously named the Kesselt Tongued Horizon (Haesaerts et al., 1981; Van Vliet-Lanoë, 1992). This is a slightly humiferous grey palaeosol characterized by a well-developed inclined tongue-shape cryoturbated base. Dating results attribute an age for the $\mathrm{NTH}$ around $22 \mathrm{ka}$ uncal $\mathrm{BP}\left({ }^{14} \mathrm{C}\right.$, Haesaerts et al., 1981), corresponding to the Weichselian late pleniglacial. The NTH constitutes a reference horizon due to its continuity in NW Europe (Lautridou, 1985; Van Vliet-Lanoë, 1992). The Eltville Tephra is usually located at about one metre beneath the NTH. This is also a marker layer for the late pleniglacial loess in Belgium, Germany and the Netherlands, usually of about 1-2 mm thick dark deposits (Semmel, 1967; Meijs et al., 1983).
According to the characteristics of the pyroclasts, the origin of the Eltville Tephra is consistent with an alkaline basaltic magma located in the east Eifel (Pouclet \& Juvigné, 2009). Recent TL data allocates an age of $20 \mathrm{ka}$ for the Eltville Tephra (Pouclet \& Juvigné, 2009).

\section{Investigation sites and methods}

The loess sequences are often studied from observable sections (quarry faces, excavations...). A detailed study of the sequence is then available. But a major limitation to study loess in detail is the scarcity of these observable sections. Moreover, they are often temporary and not deep enough. Geotechnical investigation results (mainly from drillings and cone penetration tests) could be an interesting source of complementary information that extends the loess investigation in many other places. However geotechnical tests are spatially limited and not close enough to each other compared to the spatial variability of loess. This is why regional study of loess is difficult and challenging.

\subsection{Investigated sites}

\subsubsection{Along the high-speed railway Liège-Brussels (section Bierset - Waremme)}

A geotechnical investigation campaign was performed by Belgian companies in the 1990s. These investigation works were related to the construction of the high-speed railway between Liège and Brussels. Attention has been paid on a section between Bierset and Waremme that crosses the eastern and central parts of the Hesbaye region from SE to NW. Available geotechnical data along this $18 \mathrm{~km}$ long section have been collected and summarized on a cross-section (Fig. 3). About 90 drillings and $140 \mathrm{CPT}$ results have been compiled. The tests are not homogeneously spread. They are denser along the first kilometre from Bierset and along the section west of Waremme with about 30 tests per kilometre. The rest of the cross-section is covered by about 8 tests per kilometre. The investigation depth is included between 4 and $32 \mathrm{~m}$ with a mean value of $13 \mathrm{~m}$. Due to the high resistance to penetration of the flint nodule conglomerate, penetration tests never reach the chalk layer. Most of the tests intersect the whole loess sequence.

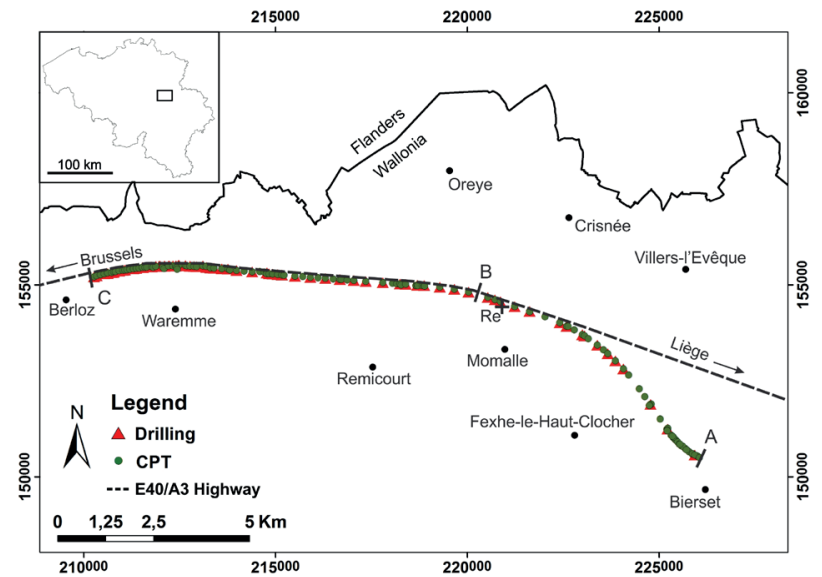

Figure 3. Location map of the tests performed along the high-speed railway Liège - Brussels (section Bierset - Waremme). Coordinates in Belgian Lambert 72. Abbreviation : $\mathrm{Re}=$ Remicourt site. Points A, B and $\mathrm{C}$ constitute arbitrary reference points along the section, also mentioned in the cross-section (see Fig. 6).

\subsubsection{Site of Remicourt}

On the site of Remicourt, 24 penetrometer tests related to the high-speed railway were performed by the Geotechnologies Laboratory of the University of Liège in 1994. The tests are distributed on a $17.5 \times 5 \mathrm{~m}^{2}$ area along the high-speed railway Liège-Brussels near the localities of Momalle and Remicourt (Figs 3,4). The spatial distribution of the CPTs corresponds to 
a regular network with $2.5 \mathrm{~m}$ spacing. This site is well known since archaeologists found about 400 artifacts attributed to Middle Palaeolithic (Bosquet et al., 2004, 2011). During the archaeological explorations (in 1997 and 1998) conducted prior to the construction of the high-speed railway, a series of trenches were realized across the loess sequence near the investigated field with CPTs (Haesaerts et al., 1997a, 1997b). They intersected a loess sequence with a maximum thickness of $20 \mathrm{~m}$. The nearest trenches (C9 and C11) were localized at $15 \mathrm{~m}$ to the South from CPTs. The loess stratigraphy study of the trenches has been compiled by Haesaerts et al. (1997a, 1999). The sequence includes loess from Middle Pleistocene, with the upper part affected by the Rocourt Pedocomplex, and a thick Late Pleistocene loess sequence characterized by the HCR, the Malplaquet Soil, the Vaux Soil, the NTH, a decarbonation limit and the Holocene Bt horizon. The lower part of the Late Pleistocene sequence of Remicourt is presented in Figure 2.

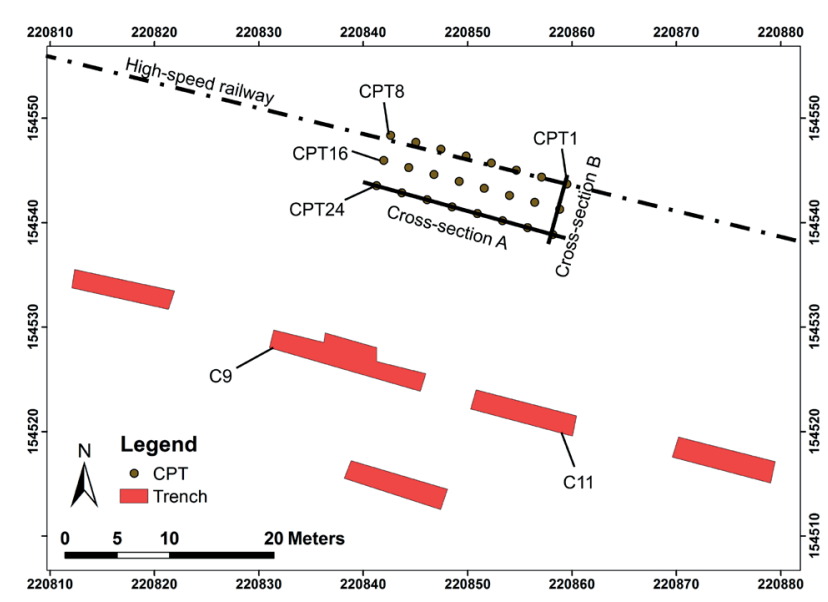

Figure 4. Location map of the investigated site of Remicourt. Coordinates in Belgian Lambert 72 .

\subsection{Cone penetration test}

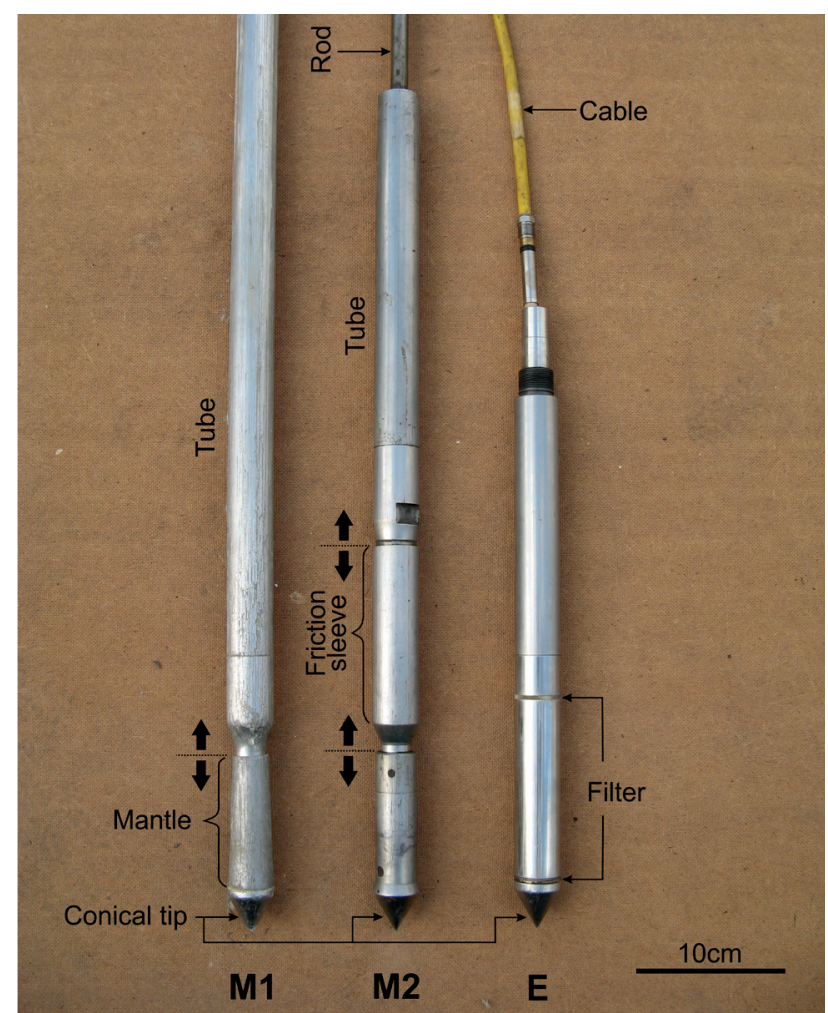

Figure 5. Different cone tips and terminology. M1 = mechanical jacke cone tip; M2 = mechanical friction jacket cone tip; $\mathrm{E}=$ electric cone tip.
Cone penetration tests (CPT) consist of pushing continuously or intermittently a cone tip at the end of a series of rods into the ground at a constant rate of $2 \mathrm{~cm} / \mathrm{s}$. For the Remicourt site, the load to push the equipment into the ground is provided by a $25 \mathrm{~T}$ lorry equipped by a HYSON $200 \mathrm{kN}$ penetrometer developed by A.P. van den Berg. The strength required to push the cone into the ground is exerted by a hydraulic system and the resulting hydraulic pressure is read on two manometers $0-20 \mathrm{MN} / \mathrm{m}^{2}$ and $0-200 \mathrm{MN} / \mathrm{m}^{2}$. The tip used in this study is a mechanical jacket cone (M1 Type) (Fig. 5). It is a common, convenient and robust mechanical tip used from the 1950s characterized by a diameter

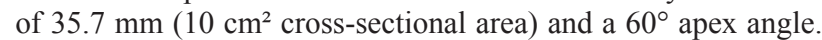
The cone resistance $\mathrm{q}_{\mathrm{c}}$ values are read each $20 \mathrm{~cm}$ on the manometers and the pushing is intermittent. The local sleeve friction $\mathrm{f}_{\mathrm{s}}$ cannot be measured with the cone M1. The applied test procedure followed the international standard ASTM D3441-05. Values of the measured cone resistance are plotted through depth on a normalized graph.

Cone tips have been continuously developed for many years to be more accurate and to measure complementary parameters to the cone resistance. Local sleeve friction can be measured with a mechanical friction jacket cone tip (cone M2, also called Begemann Type) and with an electric cone tip (Fig. 5). The cone M2 is pushed intermittently into the ground, with a measurement of $q_{c}$ and $f_{s}$ each $20 \mathrm{~cm}$ with depth. The electric cone is pushed continuously allowing a measurement each centimetre of the same parameters as the cone M2. The electric cone gives then a more detailed section of the intersected subsoil layers than the mechanical cones M1 and M2. Some electric cones are also able to measure the inclination of the tip, the pore water pressure, the conductivity (or resistivity) and the seismic wave velocity. Neither the mechanical cone M2 nor the electric cone was used in this study.

\section{Results}

\subsection{At regional scale, along the high-speed railway section}

Data obtained along the high-speed railway are presented in Figure 6. The subsoil is subdivided into five units which can be identified based on sample description from drillings and CPT interpretation. The flint nodule conglomerate of the upper part of the Gulpen Formation is the most recognizable unit due to its very high resistance to penetration. Cone resistance always reaches the maximum value $(60 \mathrm{MPa})$ allowed by the tip in this layer. The underlying chalk layer is only identified in drillings. The distinction between recent alluvium, Quaternary loess and Tertiary clays, sands and marls are also mainly based on sample observation from drillings due to its higher reliability compared to cone resistance results.

The thickness of the flint nodule conglomerate continuously decreases to the west. The mean elevation of the top of the flint nodule conglomerate also decreases to the west. This inclination has an apparent dipping of $0.3 \%$ in the orientation of the crosssection (between $\mathrm{A}$ and $\mathrm{C}$ ). If the real dipping of the same interface measured by Demoulin (1995) in the Pays de Herve region (east of Liège) is projected in the orientation of the two extremities of the cross-section, the apparent dipping becomes $0.25 \%$. This value is in good agreement with the apparent dipping observed in the Hesbaye region.

Tertiary deposits are discontinuous and mainly consist of fine sands and clays of the Sint-Huibrecht-Hern Formation east of Waremme. On the contrary the western part is characterized by a continuous Tertiary unit becoming rapidly thicker than $10 \mathrm{~m}$ which is composed of clays, sands and marls represented by the Heers, the Hannut and the Sint-Huibrecht-Hern Formations.

The Quaternary loess layer is characterized by a highly variable thickness reaching locally more than $20 \mathrm{~m}$. The establishment of the existing hydrographic network took place from the end of Tertiary when the sea receded to a NW direction. 


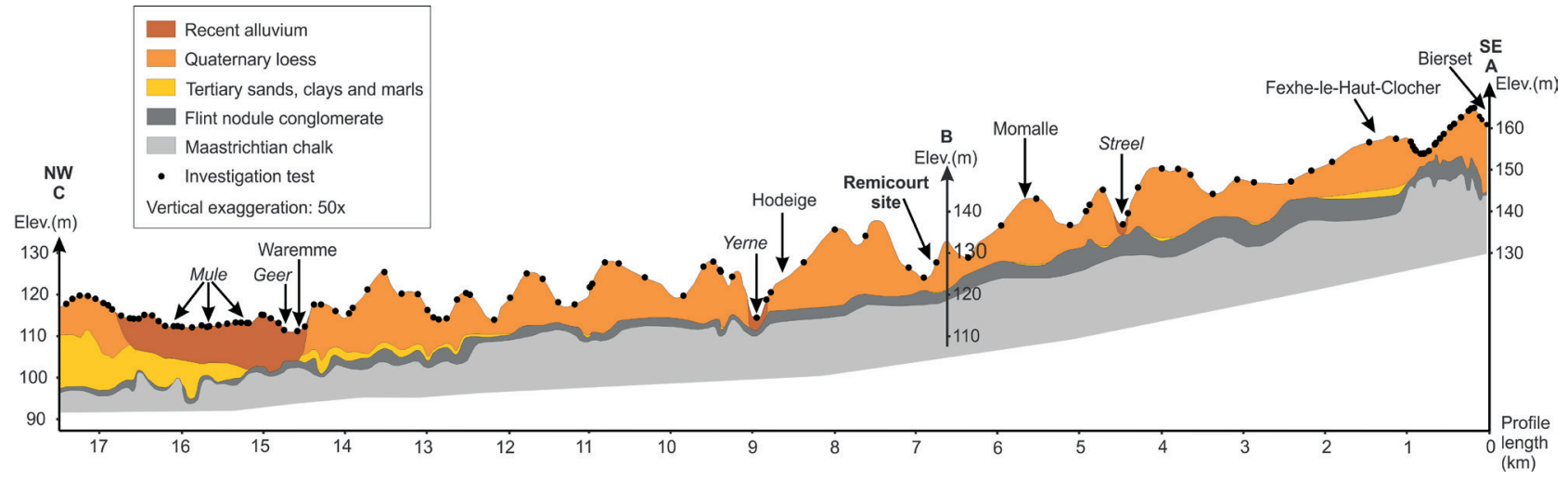

Figure 6. Cross-section of the eastern part of the Hesbaye region along the high-speed railway Liège-Brussels, between Bierset and Waremme. A vertical scale exaggeration of 50 has been considered to observe the elevation variations. The elevation data have been extracted from the NGI topographic maps at a scale of 1:10,000. Points A, B and C are also referred in Figure 3.

As a result the majority of the rivers flow from South to North. The cross-section highlights numerous N-S valleys. The majority of these valleys are now dry but were probably wet at the end of the Weichselian.

\subsection{At local scale, on the site of Remicourt}

By focusing on the Quaternary loess layer, some studies have shown that a Middle Belgium loess sequence can be schematically defined on a regional scale (Haesaerts \& Van Vliet-Lanoë, 1981; Haesaerts et al., 1999; Pirson, 2007). The Middle Belgium loess sequence has been established by comparison between different local loess sequences (e.g. Harmignies, Hélin, Remicourt, Rocourt). However many differences in the sequences also exist between the different studied sites. Moreover, the loess sequences are often affected by a high variability even at local scale (site scale). The detailed loess investigation at the site of Remicourt points out this local variability.

A detailed description of the loess stratigraphy of Remicourt (Haesaerts et al. 1997a, 1999) shows the presence of a loess ridge with a N-S axis. The ridge is composed of a well-developed Late Pleistocene loess sequence. The CPT campaign has been performed on the western side of the ridge. Based on CPT results two cross-sections (A and B) are proposed (see Fig. 4 for their location). The cross-section $\mathrm{A}$ is parallel to the trenches and includes 8 CPTs (from CPT17 to CPT24). The cross-section B is perpendicular to the previous one and intersects 3 CPTs (CPT1, CPT9 and CPT17). The location of the cross-section B has been chosen to cross the thickest loess layer investigated by the geotechnical testing campaign. Results of the two cross-sections are compared to stratigraphic descriptions proposed by Haesaerts et al. (1997a, 1999) (Figs 7A, 7B).

Based on cone resistance $\left(q_{c}\right)$ variations through depth, some stratigraphic markers can be easily defined. The limit between loess and the flint nodule conglomerate is the most recognizable marker at a depth between 5.5 and $6.5 \mathrm{~m}$. Then inside the loess sequence, four stratigraphic markers are identified based on a rapid increase or decrease of the cone resistance (Figs 7C, 7D). From the top to the bottom of the investigated sequence, these markers are detailed hereafter.

The first stratigraphic marker is located near one metre depth and is quite parallel to the ground surface. The marker is plotted at the local minimum of the cone resistance. Below this marker $\mathrm{q}_{\mathrm{c}}$ values increase. Compared to stratigraphic observations (Haesaerts et al., 1997a, 1999) the marker is stratigraphically located around the decarbonation limit and the NTH.

The second stratigraphic marker is slightly inclined to the east and is included into the lens-shape of the loess ridge. It is characterized by a drop in the $\mathrm{q}_{\mathrm{c}}$ values usually below $1 \mathrm{MPa}$. The unit defined by low cone resistance values, located below the second marker, is about 40 to $70 \mathrm{~cm}$ thick and often includes the minimum $\mathrm{q}_{\mathrm{c}}$ value of the profile. However this trend is slightly different where the layer becomes closer to the ground surface, from about $1.5 \mathrm{~m}$ depth. Then the local minimum is still usually present even if the cone resistance tends to reach more than $2 \mathrm{MPa}$. This unit is located around the HCR based on results from the trenches (Haesaerts et al., 1997a, 1999).

The third stratigraphic marker is characterized by a sharp increase in the cone resistance resulting in the transition from loose to competent loess. Cone resistance reaches values more than $4 \mathrm{MPa}$. It often corresponds to a maximum in the loess profile. The third marker is located just below the second marker. Compared to the profile its position could attribute the third marker to the top of the Rocourt Pedocomplex.

A fourth stratigraphic marker can be extracted from the central part of the cross-section A (Fig. 7C). It is parallel to the second and the third stratigraphic markers and is located about $2.2 \mathrm{~m}$ below the third one. Based on $\mathrm{q}_{\mathrm{c}}$ results it is characterized by the same trend as the third marker. However it seems to be discontinuous and laterally disappears between CPT22 and CPT23.

\section{Discussion}

The investigated site of Remicourt constitutes a great opportunity to confront detailed stratigraphic description of a well-developed loess ridge (after Haesaerts et al., 1997a, 1999) with CPT data. Their comparison gives interesting results in terms of stratigraphic marker based on the mechanical behaviour of the loess sequence. The eastern part of the Hesbaye region is characterized by a thick loess layer that overtops the flint nodule conglomerate. The transition between the two layers is sharp and clearly identifiable based on the cone resistance measurements.

Inside the Quaternary loess layer some stratigraphic markers can be identified at the study scale (i.e. site of Remicourt) based on the cone resistance measurement. The limit between the HCR and the Rocourt Pedocomplex (third stratigraphic marker) is the most noticeable marker from the $\mathrm{q}_{\mathrm{c}}$ profiles. Measurements from the Veldwezelt site (Belgium) (Vancampenhout et al., 2008) show the HCR is composed by a higher organic matter content than surrounding layers. It is well established that low cone resistance values are measured in layers highly concentrated in organic matter (Robertson et al., 1986; Lunne et al., 1997). The origin of high $\mathrm{q}_{\mathrm{c}}$ values at the transition between the HCR and the top of the Rocourt Pedocomplex is still not clearly understood. The top of the Rocourt Pedocomplex is defined by the Whitish horizon of Momalle. This horizon was probably formed during a freeze-thaw phase related to cold climatic conditions, characterized by a silty accumulation due to percolating melt water and cryoreptation (Haesaerts et al., 1999, 2011b). The induration of this horizon could then be related to a well-developed fragipan. The exact stratigraphic location of the marker needs to be confirmed by further measurements. They could be performed by a pocket penetrometer directly on the excavation faces. This light tool is able to approximate the unconfined compressive strength of the material. 
A Profile length $(m)$
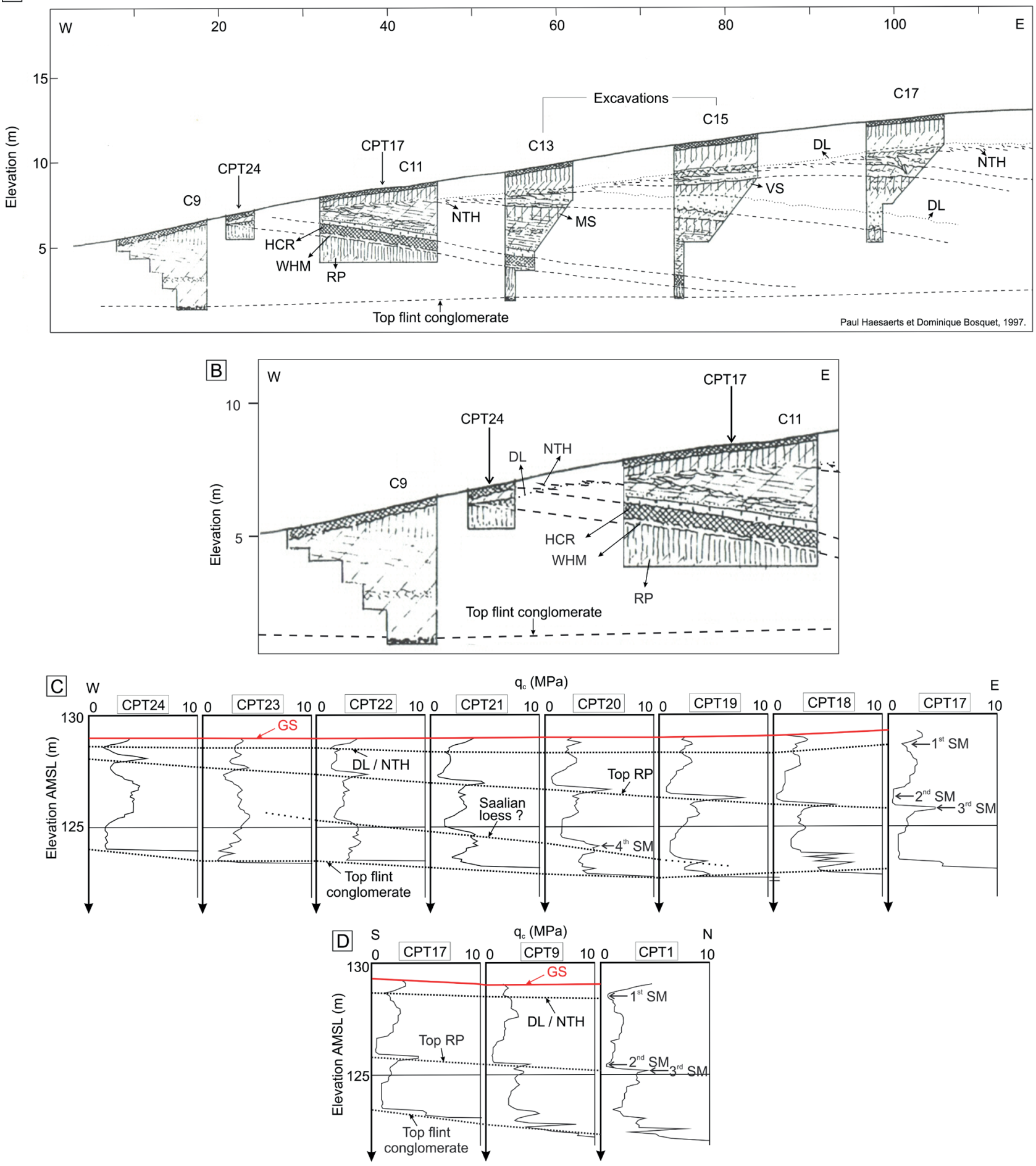

Figure 7. Profiles from the western part of the loess ridge on the site of Remicourt. The defined stratigraphic markers (SM) are plotted on C-D profiles. A. Stratigraphic cross-section of the loess ridge used as a reference for the CPT campaign interpretation (modified, after Haesaerts et al., 1999). The elevation is taken from an arbitrary origin. B. Enlargement of the stratigraphic cross-section presented in Figure 7A around the trenches C9 and C11. C. Cross-section A parallel to the trenches based on CPT results. The elevation is reported to the average mean sea level (AMSL). D. Cross-section B perpendicular to the trenches based on CPT results. The elevation is reported to the average mean sea level (AMSL). Abbreviations: DL = decarbonation limit; GS = ground surface; HCR = Humiferous Complex of Remicourt; MS = Malplaquet Soil; RP = Rocourt Pedocomplex; NTH = Nagelbeek Tongued Horizon; SM = stratigraphic marker; VS = The Vaux Soil; WHM = Whitish horizon of Momalle.

The transition between the HCR and the Rocourt Pedocomplex (third stratigraphic marker) seems to become less clear when the horizons are located less than $2 \mathrm{~m}$ depth, near the decarbonation limit (see CPT $22-24$, Fig. 7C). High values of the $\mathrm{q}_{\mathrm{c}}$ at the top of the Rocourt Pedocomplex are still well observable while the HCR is characterized by higher values in $\mathrm{q}_{\mathrm{c}}$ than elsewhere when the horizon is deeper. This could be due to the influence of a higher carbonate concentration just below the decarbonation limit. An increase in resistance of loess with higher carbonate content has already been observed from pocket penetrometer measurements (Amorosi et al., 2015). Furthermore the CPT 22 to 24 were performed at the western extremity of the lens-shape loess sequence. As a consequence the HCR is probably thinner than in the central part of the lens-shape where it has been preserved. The HCR could then be hidden around the CPT 22 to 24.

The first stratigraphic marker could be related to either the decarbonation limit, with high carbonate content below this limit, or the NTH. It seems more likely that the first stratigraphic marker is originated from a higher carbonate content. However the decarbonation limit and the NTH are stratigraphically too 
close enough in the investigated site to make more accurate the stratigraphic correlation with the marker.

Finally the fourth stratigraphic marker appears as discontinuous. It is parallel to the second and the third previously defined markers. It is characterized by a rapid increase in $q_{c}$ values. The study of Haesaerts et al. (1999) refers the existence of very compact units related to the Late Saalian glaciation that have only been observed on the western side of the loess ridge. Further investigations are needed to confirm the origin of the fourth marker.

From a geomorphological point of view the CPT campaign confirms the lens-shape of the western part of the loess ridge. The cross-section $\mathrm{B}$ also indicates the layers that compose the ridge slightly deepen to the North. The 3D morphology of each marker horizon can then be characterized. The decarbonation limit is closely parallel to the ground surface while the top of the HCR and the top of the Rocourt Pedocomplex deepen to the NE.

To ensure the stratigraphic correlation between cone resistance values and lithology, it should be really interesting to perform measurements of the compressive strength properties directly from the trenches or from undisturbed core samples coming from the investigated site. Unfortunately the trenches were filled up and no core samples are available for further analysis.

Results are based on measurements of the cone resistance $\left(q_{c}\right)$ from a mechanical cone tip M1. It is a very commonly used tip with measurements each $20 \mathrm{~cm}$ with depth. Electric tips have recently been developed and give access to measurements every centimetre with depth. With such kind of tips, the investigated section is more detailed and loess layers/horizons with a thickness of some centimetres only can be detected. An electric cone has recently been tested on the site of Romont (Eben-Emael, Belgium) and gives complementary promising results (Delvoie et al., 2016). This equipment significantly increases the accuracy of the investigated loess sequence. Moreover the electric tips also measure the sleeve friction $\left(f_{s}\right)$ which could give access to the definition of additional stratigraphic markers.

\section{Conclusions and perspectives}

The geotechnical investigation along a section (BiersetWaremme, eastern part of the Hesbaye region, Belgium) of the high-speed railway Liège-Brussels specifies the geological setting at regional scale. The loess layer is characterized by a very high variability in its thickness. It can locally reach $20 \mathrm{~m}$ thick. Continuous Tertiary deposits appear around Waremme (in the cross-section) and thicken to the west. The flint nodule conglomerate layer located on top of the Maastrichtian chalk thickens to the SW. The lower surface of the Tertiary deposits is characterized by a $0.3 \%$ apparent dipping to the NW.

A site located along the high-speed railway Liège-Brussels has been studied in more detail. The site of Remicourt (SE of the Hesbaye region, Belgium) has been investigated by a CPT campaign located very close to a series of trenches allowing a detailed stratigraphic description of the intersected loess sequence (after Haesaerts et al., 1997a, 1999). Results of the stratigraphic observations reveal a well-developed lens-shape loess sequence including the upper part of the Middle Pleistocene and Late Pleistocene.

Comparison between the CPTs performed on the site of Remicourt and the detailed stratigraphic description, indicates cone resistance $\left(\mathrm{q}_{\mathrm{c}}\right)$ measurements are able to define some stratigraphic markers within the loess layer. The most recognizable marker is the transition between the Humiferous Complex of Remicourt and the Rocourt Pedocomplex. The lens-shape of the loess sequence is confirmed by the CPT interpretation. Furthermore the 3D morphology of each stratigraphic marker can be estimated from the available data. The results show that the layers included into the western part of the loess ridge deepen to the NE.
These preliminary results in terms of stratigraphic markers offer interesting perspectives for archaeological applications. CPTs easily penetrate the loess layer until its basement. They could then be used complementary with common and cheap investigation techniques as the hand auger drilling technique in areas far from direct observable sections. Moreover the most significant stratigraphic marker is located around the transition between the HCR and the Rocourt Pedocomplex. These units include the majority of the archaeological materials found in Middle Belgium related to Middle Palaeolithic (Pirson \& Di Modica, 2011).

The penetration equipment used is this study consists in a mechanical cone jacket (M1 Type) with discontinuous (each $20 \mathrm{~cm}$ ) measurements of the cone resistance with depth. Recent developments in electric cones allow to investigate the mechanical properties every centimetre by measuring the cone resistance $\left(q_{c}\right)$ and the sleeve friction $\left(f_{s}\right)$. This approach has recently been tested on the site of Romont (Eben-Emael, Belgium) and leads to complementary promising results (Delvoie et al., 2016). Further investigations could result in the definition of stratigraphic markers at regional scale based on a geotechnical approach.

Strength measurements from the excavation faces are also needed to definitely validate the stratigraphic position of the observed markers. Indeed the distance between the excavation faces and the CPTs induces an uncertainty of the exact stratigraphic position of the markers. This could be performed with a light tool like a pocket penetrometer which is able to approximate the unconfined compressive strength. Unfortunately the trenches from the site of Remicourt were filled up. The methodology could then be applied to another site where an interesting thick loess layer exists and where a section cuts the loess sequence. These complementary measurements will be performed in the quarry of Romont (Eben-Emael, Belgium).

\section{Acknowledgements}

The authors acknowledge Infrabel company to authorize the diffusion of the results related to the investigation campaign along the high-speed railway Liège-Brussels. The study of the site of Remicourt would not have been possible without the technical support of the Geotechnical Laboratory of the University of Liège. We also want to thank Jean-Louis Pingot (Catholic University of Louvain), Alain Demoulin (University of Liège), as well as Dominique Bosquet and Pierre van der Sloot (Direction de l'Archéologie du Service public de Wallonie) for the interesting discussions about results mentioned in this paper. We gratefully acknowledge Stéphane Pirson (Direction de l'Archéologie du Service public de Wallonie) and an anonymous reviewer for the significant comments. This work was made possible by funding support from the University of Liège.

\section{References}

Alvarez, R. \& Steinbach, H.S., 2009. A review of the effects of tillage systems on some soil physical properties, water content, nitrate availability and crops yield in the Argentine Pampas. Soil and Tillage Research, 104, 1-15.

Amorosi, A., Bruno, L., Campo, B. \& Morelli, A., 2015. The value of pocket penetration tests for the high-resolution palaeosol stratigraphy of late Quaternary deposits. Geological Journal, 20, 670-682.

Antoine, P., Rousseau, D.D., Degeai, J.P., Moine, O., Lagroix, F., Kreutzer, S., Fuchs, M., Hatté, C., Gauthier, C., Svoboda, J. \& Lisá, L., 2013. High-resolution record of the environmental response to climatic variations during the Last Interglacial-Glacial cycle in Central Europe: The loess-palaeosol sequence of Dolní Věstonice (Czech Republic). Quaternary Science Reviews, 67, 17-38.

ASTM D2487-06, 2006. Standard Practice for Classification of Soils for Engineering Purposes (Unified Classification System). ASTM International, West Conshohocken, PA. http://dx.doi.org/10.1520/ D2487-06.

ASTM D3441-05, 2005. Standard Test Method for Mechanical Cone Penetration Tests of Soil (Withdrawn 2014), ASTM International, West Conshohocken, PA. http://dx.doi.org/10.1520/D3441-05.

Bosquet, D., Jardón Giner, P. \& Jadin, I., 2004. L'industrie lithique du 
site paléolithique moyen de Remicourt «En Bia Flo » (province de Liège, Belgique) : technologie, tracéologie et analyse spatiale. British Archaeological Reports. International Series, 1239, 257-274.

Bosquet, D., Haesaerts, P., Damblon, F., Jardón Giner, P. \& Ryssaert, C., 2011. Le gisement paléolithique de Remicourt-En Bia Flo I. In : Toussaint, M., Di Modica, K. \& Pirson, S. (eds). Le Paléolithique moyen en Belgique. Mélanges Marguerite Ulrix-Closset. Bulletin de la Société royale belge d'Études géologiques et archéologiques «Les Chercheurs de la Wallonie » (hors-série ${ }^{\circ} 4$ ) et Etudes et Recherches archéologiques de 1'Université de Liège (n`128), 375-384.

Bustamante, M. \& Gianeselli, L., 1982. Pile bearing capacity prediction by means of static penetrometer CPT. Proceedings of the 2nd European Symposium on Penetration Testing, ESOPT-II, Amsterdam, 493500.

Buylaert, J.P., Murray, A.S., Vandenberghe, D., Vriend, M., De Corte, F. \& Van den haute, P., 2008. Optical dating of Chinese loess using sand-sized quartz: Establishing a time frame for Late Pleistocene climate changes in the western part of the Chinese Loess Plateau. Quaternary Geochronology, 3, 99-113.

De Geyter, G., 1988. Formatie van Hannut. In Maréchal, R. \& Laga, P. (eds), Voorstel lithostratigrafische indeling van het Paleogeen. Belgische Geologische Dienst, Brussel, 60-71.

de Heinzelin, J., 1984. Essai sur archéologie et régions naturelles. In Cahen, D. \& Haesaerts, P. (eds), Peuples chasseurs de la Belgique préhistorique dans leur cadre naturel. Institut Royal des Sciences Naturelles de Belgique, Bruxelles, 101-106.

Delvoie, S., Pirson, S., Charlier, R. \& Collin, F., 2016. Etude da la séquence stratigraphique des loess de la carrière de Romont (Eben-Emael, Belgique) par une campagne géotechnique. Notae Praehistoricae, 36, 5-21.

Demoulin, A., 1995. Les surfaces d'érosion méso-cénozoïques en Ardenne-Eifel. Bulletin de la Société géologique de France, 166, 573-585.

Demoulin, A., 1998. Testing the tectonic significance of some parameters of longitudinal river profiles: the case of the Ardenne (Belgium, NW Europe). Geomorphology, 24, 189-208.

Ding, Z.L., Xiong, S.F., Sun, J.M., Yang, S.L., Gu, Z.Y. \& Liu, T.S., 1999. Pedostratigraphy and paleomagnetism of a $\sim 7.0 \mathrm{Ma}$ eolian loess-red clay sequence at Lingtai, Loess Plateau, north-central China and the implications for paleomonsoon evolution. Palaeogeography, Palaeoclimatology, Palaeoecology, 152, 49-66.

Frechen, M., Van Vliet-Lanoë, B. \& Van den Haute, P., 2001. The Upper Pleistocene loess record at Harmignies/Belgium - high resolution terrestrial archive of climate forcing. Palaeogeography, Palaeoclimatology, Palaeoecology, 173, 175-195.

Frechen, M., Oches, E.A. \& Kohfeld, K.E., 2003. Loess in Europemass accumulation rates during the Last Glacial Period. Quaternary Science Reviews, 22, 1835-1857.

Grunwald, S., Lowery, B., Rooney, D.J. \& McSweeney, K., 2001. Profile cone penetrometer data used to distinguish between soil materials. Soil and Tillage Research, 62, 27-40.

Gullentops, F., 1954. Contribution à la chronologie du Pléistocène et des formes du relief en Belgique. Mémoires de l'Institut géologique de 1'Université Catholique de Louvain, 18, 125-252.

Guo, Y., Huang, C.C., Pang, J., Zha, X., Zhou, Y., Zhang, Y. \& Zhou, L., 2013. Sedimentological study of the stratigraphy at the site of Homo erectus yunxianensis in the upper Hanjiang River valley, China. Quaternary International, 300, 75-82.

Haase, D., Fink, J., Haase, G., Ruske, R., Pecsi, M., Richter, H., Altermann, M. \& Jaeger, K.D., 2007. Loess in Europe: its spatia distribution based on a European loess map, scale 1:2,500,000. Quaternary Science Reviews, 26, 1301-1312.

Haesaerts, P., 1978. Contexte stratigraphique de quelques gisements paléolithiques de plein air de Moyenne Belgique. Bulletin de la Société Royale Belge d'Anthropologie et de Préhistoire, 85, 115133.

Haesaerts, P. \& Mestdagh, H., 2000. Pedosedimentary evolution of the last interglacial and early glacial sequence in the European loess belt from Belgium to central Russia. Netherlands Journal of Geosciences, 79, 313-324

Haesaerts, P. \& Van Vliet, B., 1974. Compte rendu de l'excursion du 25 mai 1974 consacrée à la stratigraphie des limons aux environs de Mons. Annales de la Société géologique de Belgique, 97, 547-560.

Haesaerts, P. \& Van Vliet-Lanoë, B., 1981. Phénomenes périglaciaires et sols fossiles observés à Maisières-Canal, à Harmignies et à Rocourt. Biuletyn peryglacjalny, 28, 291-324.

Haesaerts, P., Mestdagh, H. \& Bosquet, D., 1997a. La séquence de Remicourt (Hesbaye, Belgique). Notae Praehistoricae, 17, 45-52.

Haesaerts, P., Mestdagh, H. \& Bosquet, D., 1997b. I. Analyse des dépôts quaternaires sur le tracé du TGV oriental. II. Le site de RemicourtMomalle, au lieu dit En Bia Flo. Institut Royal des Sciences Naturelles de Belgique, Bruxelles, rapport inédit, $12 \mathrm{p}$.

Haesaerts, P., Mestdagh, H. \& Bosquet, D., 1999. The sequence of
Remicourt (Hesbaye, Belgium): new insights on the pedo- and chronostratigraphy of the Rocourt soil. Geologica Belgica, 2, 5-27.

Haesaerts, P., Pirson, S. \& Meijs, E., 2011a. Romont Group. In National Commission for Stratigraphy in Belgium (ed.), Quaternary lithostratigraphic units (Belgium). http://ncs.drupalgardens.com/ quaternary/41-romont-group-0, accessed 09/05/2016.

Haesaerts, P., Di Modica, K. \& Pirson, S., 2011b. Le gisement paléolithique de la Sablière Gritten à Rocourt (province de Liège). In Toussaint, M., Di Modica, K. \& Pirson, S. (eds). Le Paléolithique moyen en Belgique. Mélanges Marguerite Ulrix-Closset. Bulletin de la Société royale belge d'Études géologiques et archéologiques « Les Chercheurs de la Wallonie » (hors-série ${ }^{\circ} 4$ ) et Etudes et Recherches archéologiques de l’Université de Liège (n¹28), 359-374.

Haesaerts, P., Juvigné, E., Kuyl, O., Mucher, H. \& Roebroeks, W., 1981. Compte rendu de l'excursion du 13 juin 1981, en Hesbaye et au Limbourg néerlandais, consacrée à la chronostratigraphie des loess du Pléistocène supérieur. Annales de la Société géologique de Belgique, 104, 223-240.

Haesaerts, P., Borziak, I., Chekha, V.P., Chirica, V., Damblon, F., Drozdov, N.I., Orlova, L.A., Pirson, S. \& van der Plicht, J., 2009. Climatic signature and radiocarbon chronology of Middle and Late Pleniglacial loess from Eurasia: comparison with the marine and Greenland records. Radiocarbon, 51, 301-318.

Juvigné, E., 1977. Zone de dispersion et âge des poussières volcaniques du Tuf de Rocourt. Annales de la Société géologique de Belgique, $100,13-22$

Juvigné, E., 1993. Contribution à la téphrostratigraphie du Quaternaire et son application à la géomorphologie. Mémoire pour servir à l'Explication des Cartes Géologiques et Minières de la Belgique, 36, $66 \mathrm{p}$.

Juvigné, E. \& Semmel, A., 1988. Un tuf volcanique semblable à l'Eltviller Tuff dans les loess de Hesbaye (Belgique) et du Limbourg neerlandais. Eiszeitalter und Gegenwart, 31, 83-90.

Juvigné, E., Tallier, E., Haesaerts, P. \& Pirson, S., 2008. Un nouveau stratotype du Téphra de Rocourt dans la carrière de Romont (Eben/ Bassenge, Belgique). Quaternaire, 19, 133-139.

Juvigné, E., Pouclet, A., Haesaerts, P., Bosquet, D. \& Pirson, S., 2013. Le Téphra de Rocourt dans le site paléolithique moyen de Remicourt (Province de Liège, Belgique). Quaternaire, 24, 279-291.

Laga, P., 1988. Formatie van Sint-Huitbrechts-Hern. In Maréchal, R. \& Laga, P. (eds). Voorstel lithostratigraphische indeling van het Paleogeen. Belgische Geologische Dienst, Brussel, 164-169.

Laga, P. \& De Geyter, G., 1988. Formatie van Heers. In Maréchal, R. \& Laga, P. (eds). Voorstel lithostratigraphische indeling van het Paleogeen. Belgische Geologische Dienst, Brussel, 52-58.

Lautridou, J.P., 1985. Le cycle périglaciaire pléistocène en Europe du nord-ouest et plus particulièrement en Normandie. Thèse de doctorat d'Etat, Université de Caen, Centre de Géomorphologie du CNRS, 907 p.

Lunne, T., Robertson, P.K. \& Powell, J.J.M., 1997 (eds). Cone Penetration Testing in Geotechnical Practice. Spon Press, London, 312 p.

Meijs, E., Mucher, H., Ouwerkerk, G., Romein, A. \& Stoltenberg, H., 1983. Evidence of the presence of the Eltville tuff layer in Dutch and Belgian Limbourg and the consequences for the loess stratigraphy. Eiszeitalter und Gegenwart, 33, 59-78.

Paepe, R., 1967a. Comparable stratigraphy of Würm loess deposits in Belgium and Austria. Bulletin de la Société belge de Géologie, Paléontologie et Hydrologie, 75, 203-216.

Paepe, R., 1967b. Séquences litho-stratigraphiques du Pléistocène supérieur - Datations au C14. Bulletin de la Société belge de Géologie, Paléontologie et Hydrologie, 76, 171-182.

Pécsi, M., 1990. Loess is not just the accumulation of dust. Quaternary International, 7-8, 1-21.

Pécsi, M., 1995. The role of principles and methods in loess-paleosol investigations. GeoJournal, 36, 117-131.

Pirson, S., 2007. Contribution à l'étude des dépôts d'entrée de grotte en Belgique au Pléistocène supérieur. Stratigraphie, sédimentogenèse et paléoenvironnement. Thèse de doctorat, Université de Liège et Institut royal des Sciences naturelles de Belgique, $435 \mathrm{p}$.

Pirson, S. \& Di Modica, K., 2011. Position chronostratigraphique des productions lithiques du Paléolithique ancien en Belgique : un état de la question. In Toussaint, M., Di Modica, K. \& Pirson, S. (eds). Le Paléolithique moyen en Belgique. Mélanges Marguerite UlrixClosset. Bulletin de la Société royale belge d'Études géologiques et archéologiques «Les Chercheurs de la Wallonie » (hors-série n ${ }^{\circ}$ ) et Etudes et Recherches archéologiques de 1'Université de Liège $\left(n^{\circ} 128\right), 105-148$.

Pirson, S. \& Juvigné, E., 2011. Bilan sur l'étude des téphras à la grotte Walou. In Pirson, S., Draily, C. \& Toussaint, M. (eds). La grotte Walou à Trooz (Belgique). Fouilles de 1996 à 2004. Volume 1. Les sciences de la terre. Service public de Wallonie, Namur, Etudes et Documents, Archéologie, 20, 134-167.

Pirson, S., Haesaerts, P. \& Di Modica, K., 2009. Cadre 
chronostratigraphique des principaux gisements du Paléolithique moyen du bassin de la Haine: un état de la question. In Di Modica, K. \& Jungels, C. (eds), Paléolithique moyen en Wallonie. La collection Louis Eloy, Collections du Patrimoine culturel de la Communauté française, 2, 58-77.

Pirson, S., Haesaerts, P., Court-Picon, M., Damblon, F., Toussaint, M., Debenham, N. \& Draily, C., 2006. Belgian cave entrance and rock-shelter sequences as palaeoenvironmental data recorders: the example of Walou cave. Geologica Belgica, 9, 275-286.

Pouclet, A. \& Juvigné, E., 2009. The Eltville tephra, a late Pleistocene widespread tephra layer in Germany, Belgium and The Netherlands; symptomatic compositions of the minerals. Geologica Belgica, 12, 93-103.

Pouclet, A., Juvigné, E. \& Pirson, S., 2008. The Rocourt Tephra, a widespread 90-74 ka stratigraphic marker in Belgium. Quaternary Research, 70, 105-120.

Robaszynski, F., 2006. Maastrichtian. Geologica Belgica, 9, 63-72.

Roberts, H.M., 2008. The development and application of luminescence dating to loess deposits: A perspective on the past, present and future. Boreas, 37, 483-507.

Robertson, P.K., Campanella, R.G., Gillespie, D. \& Greig, J., 1986. Use of piezometer cone data. Proceedings of the ASCE Specialty Conference In Situ '86: Use of In Situ Tests in Geotechnical Engineering. American Society of Engineers (ASCE), Blacksburg, 1263-1280.

Schellenberger, A. \& Veit, H., 2006. Pedostratigraphy and pedological and geochemical characterization of Las Carreras loess-paleosol sequence, Valle de Tafí, NW-Argentina. Quaternary Science Reviews, 25, 811-831.

Semmel, A., 1967. Neue Fundstellen von vulkanischem Material in hessischen Lössen. Notizblatt des Hessischen Landesamtes für Bodenforschung zu Wiesbaden, 95, 104-108.

Smykatz-Kloss, W., Smykatz-Kloss, B., Naguib, N. \& Zöller, L., 2004. The reconstruction of palaeoclimatological changes from mineralogical and geochemical compositions of loess and alluvial loess profiles. In Smykatz-Kloss, W. \& Felix-Henningsen, P. (eds). Palaeoecology of Quaternary Drylands. Springer, Berlin, Lecture Notes in Earth Sciences, 102, 101-118.

Tonni, L. \& Gottardi, G., 2011. Analysis and interpretation of piezocone data on the silty soils of the Venetian lagoon (Treporti test site). Canadian Geotechnical Journal, 48, 616-633.

Van den Haute, P., Frechen, M., Buylaert, J.P., Vandenberghe, D. \& De Corte, F., 2003. The Last Interglacial palaeosol in the Belgian loess belt: TL age record. Quaternary Science Reviews, 22, 985-990.

Van Vliet-Lanoë, B., 1990. Le pédocomplexe de Warneton, où en eston ? Bilan paléopédologique et micromorphologique. Quaternaire, $1,65-75$.

Van Vliet-Lanoë, B., 1992. Le niveau à langues de Kesselt, horizon repère de la stratigraphique du Weichsélien supérieur européen : signification paléoenvironnementale et paléoclimatique. Mémoires de la Société géologique de France, 160, 35-44.

Vancampenhout, K., Wouters, K., Caus, A., Buurman, P., Swennen, R. \& Deckers, J., 2008. Fingerprinting of soil organic matter as a proxy for assessing climate and vegetation changes in last interglacial palaeosols (Veldwezelt, Belgium). Quaternary Research, 69, 145162.

Zhang, G., Robertson, P.K. \& Brachman, R.W.I., 2002. Estimating liquefaction-induced ground settlements from CPT for level ground. Canadian Geotechnical Journal, 39, 1168-1180. 